\title{
Emotional Intelligence, Social Support and General Well-Being of Working and Non-Working Muslim Women
}

\author{
Dr. Nishat $\mathrm{Afroz}^{1 *}$
}

\section{ABSTRACT}

The purpose of the study was to identify and compare the emotional intelligence, general wellbeing and social support of working and non-working Muslim women and to find out the relationship between emotional intelligence, general well-being and social support of Muslim women. Sample of the study comprised of 80 females subjects divided into two groups. One group was consisted of 40 working females from teaching profession and other group was consisted of 40 non-working females i.e., housewives. All subjects were belonged to Muslim religion and were drawn from the city of Varanasi. Data have been analysed by using descriptive analysis, t-test, and coefficient of correlation. Findings indicated that working and non-working Muslim females did not differ on any of the scale i.e., emotional intelligence, general well-being and social-support.

Keywords: Emotional Intelligence, General Well-Being, Social-Support, Muslim Women

The sense of one's identity or self is an important dimension of individual's personality giving each of us a unique individuality. Today society has given equal opportunity to male and female both. Male and female both are aware and sensitive to their needs, aspirations and rights and are asserting them through economic route. A concern for their self-worth and identity, their independence, their individuality, their right, their ability to self-actualize has therefore prime importance to social scientists (Afroz \& Mittra, 2011).

Men and women considered as two wheels of vehicles of a society, both wheels should work equally to move the vehicle of society. Women constitute approximately half of the world's population yet they are placed at various disadvantageous positions due to gender differences. Women have been socially, economically, physically, psychologically and sexually exploited sometime in the name of religion and sometimes by the customs and traditions.

\footnotetext{
${ }^{1}$ Department of Psychology, MMV, Banaras Hindu University, Varanasi, UP, India *Responding Author

(C) 2016 I N Afroz; licensee IJIP. This is an Open Access Research distributed under the terms of the Creative Commons Attribution License (http://creativecommons.org/licenses/by/2.0), which permits unrestricted use, distribution, and reproduction in any Medium, provided the original work is properly cited.
} 


\section{Emotional Intelligence, Social Support and General Well-Being of Working and Non-Working Muslim Women}

In India Muslims are considered an important pillar of the society which has a power of its own. Studies on Indian Muslims reveal a unique kind of cultural assimilation of Muslims with the rest of the society. They have preserved their originality, yet they have become an integral part of Indian composite culture. Muslim women in India are potential catalyst for development and nation building, even though they are in a minority. Their emancipation may be a crucial step in the development of community. Their present status by and large reflects the dominance of traditional attitude. An improvement in their present status will not only contribute in the progress and transformationof the community but also the development of the entire nation.

Indian Muslims are a highly diverse community. All Indian Muslims are not miserable. Many of them are well placed, properly educated and reasonably liberal. However, most of the Indian women in general and Muslim women in particular are suffering and struggling against atrocities inside as well as outside the households. Both family and society are equally hostile to them (Kumar \& Varghese, 2005).Muslim women in general are one of the most underprivileged groups, their literacy rate is lower, and they are economically disadvantaged and politically marginalized section of Indian society.

Earlier women in India were considered only as the homemaker, their prime responsibility was to take care of their families, did not go out to earn their livelihood and those women who were working were less valued and not respected in the society. But the condition of women has remarkably changed over the years. This change is notable because previously women had to dependent on men for the economic matter but now they have total control of their economic fates. Increasing awareness and education also creates a favorable change in the condition of the females who are not working. Today homemakers have also many channels or paths through which they can express themselves, indulge in some creative and satisfying activities. Many job opportunities have emerged and are knocking which are suitable according to the perspectives of Muslim women without being out of their religious norms. So, all these opportunities might have created a remarkable cum favorable changes in the condition of working and nonworking Muslim women.

Indian women in general and Muslim females in particular have been gradually coming out of traditional roles and entering into the male dominated areas. In recent years the role and status of the females have been changed tremendously. With increasing female education and more liberty for their rights and privileges, women's attitude towards their stereotyped role is changed. Their participation in education and work place has also led to their increased socio-familial roles. Women who work outside the home are required to make many adjustments that may contribute stress and anxiety. The problem of stress in women, particularly working women, is an important aspect on the process of social and emotional changes. Increase in females' participation in work 


\section{Emotional Intelligence, Social Support and General Well-Being of Working and Non-Working Muslim Women}

force has led to the increased interest in the effects of employment on their well-being, which can be either beneficial or detrimental to women's well-being(Elgar \& Chester, 2007).

Studies have revealed that finding and getting social support is one of the most effective ways to cope with stress and anxiety. The social support is the availability of helping relationships and increasing the quality of those relationships. Social support can be divided into two parts such as organizational support and family related support (Brough \& Pears, 2004). Work related social support comes from the organizational members, such as peers and supervisors, where an employee works, whereas personal social support comes from spouse, parents, children, extended family or friends. However, researchers found that support from the husband was positively associated to curb out conflict (Aryee, 1992). Social support is believed to have a positive impact on the working roles performed by women at work places by enhancing job satisfaction and creating balance between work and family, emotionally capable, thereby eliminating work-family conflicts. It is one of the important resources for working women to manage their work and family domains.

The impact of hard work with little appreciation and no social support would play a negative effect on the emotional, physical and psychological health of these women. The feeling of guilt among these women from their perceived inability to be as good in meeting the family and home needs in comparison to housewives is important to address. Based on this background, a need was identified to explore impact of working status on the lives of working women.

In the last ten years, the concept of emotional intelligence has aroused much interest in society and in academia. Emotional Intelligence is the ability or tendency to perceive, understand, regulate and harness emotions adoptively in self and others.Emotional intelligence is a dynamic construct influenced by diverse biological, psychological, and social factors. A good deal of research has been conducted on emotional intelligence and it was found to be appearing as an important factor in the prediction of personal, academic and career success.

Studies on emotional intelligence with respect to various psychosocial correlates have been found in a variety of fields. Empirical studies investigating the relationship of emotional intelligence with numerous psychological and psychosocial factors were reported by several researchers and simultaneously revealing the significance of emotional intelligence and its beneficial aspects with remarkable contribution in the field of interpersonal relationships, success in work and personal life, health psychology, managing occupational stress, academic field, improving personality, enhancing performance and many more positive behavior patterns (Gallagher \&Vella-Brodrick, 2008; Mavroveli, Petrides, Reiffe, \& Baker,2007; Van Rooy \& Viswesvaran, 2004; Schute, Malouff, Hall, Haggerty, Cooper, Golden, \& Dornheim, 1998; 


\section{Emotional Intelligence, Social Support and General Well-Being of Working and Non-Working Muslim Women}

Adeyemo, 2005; Tsaousis\& Nikolaou,2005;Trinidad \& Johnson, 2001; Brackett \& Mayer, 2003; Asha \& Hangal, 2001).

Today women are working outside the home, moving into the domains traditionally reserved for males, and vigorously pursuing careers and interests. Women can make contributions to their present and future environments at many levels. Some channel their creativity into raising children, homemaking, relationships with loved ones, or getting to know and love themselves well. Professional women, as the category label suggest are urban, well educated women, employed in different fields. These women did not necessarily have an easy time working in the male world but were certainly better educated and they considered work to be an expression of self.

Studies indicate that there is positive relationship between emotional intelligence, general wellbeing and social support. The present study attempts to examine the relationship between the emotional intelligence, social support, and general well-being of working and non-working women. General well-being is heavily tied to our emotional intelligence. Only by being aware of our emotional state and our reaction to stress in our life we hope to manage stress and maintain good health. Many studies were done to examine the relationship between emotional intelligence, general well-being, and social support among women. Present study attempted to examine the relationship of these three variables among Muslim females because even today females' especially Muslim females faces many difficulties and constraints regarding pursuing a job. They face problems in finding jobs compatible with their religious norms and beliefs. Working environment also create many difficulties. They even lack the support of their families. All this ultimately started influencing their daily life functioning and lowers the general wellbeing level. The implications of the study will help to provide a better condition for working Muslim women. Thus keeping on the view the following objectives were formulated:

\section{Objectives:}

1. To identify the emotional intelligence, general well-being and social support of working and non-working Muslim women.

2. To assess the relationship between emotional intelligence, general well-being and social support of working and non-working Muslim women.

3. To compare the working and non-working Muslim women on the basis of emotional intelligence, social support, and general well-being.

\section{Hypotheses:}

1. The relationship between emotional intelligence and general well-being will be positive i.e., better the emotional intelligence better the general well-being.

2. The relationship between emotional intelligence and social support will be positive i.e., better the emotional intelligence better the social support.

(c) The International Journal of Indian Psychology, ISSN 2348-5396 (e) | ISSN: 2349-3429 (p) | 9 


\section{Emotional Intelligence, Social Support and General Well-Being of Working and Non-Working Muslim Women}

3. The relationship between social support and general well-being will be positive i.e., better the social support better the general well-being.

4. Non-working Muslim women will score higher on all these three i.e., emotional intelligence, social support and general well-being in comparison to working Muslim women.

\section{METHOD:}

\section{Sample:}

Sample of the study comprised of 80 females subjects divided into two groups. One group was consisted of 40 working females from teaching profession and other group was consisted of 40 non-working females i.e., housewives. All subjects were belonged to Muslim religion and were drawn from Varanasi with the help of simple random sampling technique. All the subjects were belonged to the age range of 30-45 years of age.

\section{Tools:}

The tools used for the study are:

\section{Mangal Emotional Intelligence Inventory:}

It is developed by Mangal and Mangal(1971). It consists of 100 items, 25 each from four aspects of emotional intelligence namely, intrapersonal awareness, interpersonal awareness, intrapersonal management, interpersonal management. The mode of response to the item of the inventory is yes or no with the proposed statement. The reliability coefficients derived from test retest method are $.89, .90$, and .92 respectively.

\section{PGI General Well Being Measure:}

It is developed by Verma and Verma(2005). It consists of 20 items which measures the general well-being. Items were tested through thinking aloud method for their suitability. Its difficulty value is judged by underlining test and was found to be quiet low and highly satisfactory. The test retest reliability for the English and Hindi version of the test is .91and .86.

\section{Social Support Scale:}

It is developed by Asthana and Verma (2005). It consists of 35 items out of which 25 are positively worded and 10are negatively worded items, which measures the three dimensions of social support i.e., emotional support, informational support, and instrumental support. The responses are to be obtained on five point rating scale. The test retest reliability of the test is .81 .

\section{Procedure}

A sample of 80 females (40 working and40 non-working) of age group 30-45 years drawn from Varanasi with the help of simple random sampling method was selected for the study. All subjects were Muslim women. The tools were arranged in order and all the working women and non-working women (housewives) were personally contacted in their respective workplace and homes. Before the conduction of the test, necessary information regarding the test was provided to the subjects who were interested to take part in the test. Then after having subjects' consent, 


\section{Emotional Intelligence, Social Support and General Well-Being of Working and Non-Working Muslim Women}

tests were given to the subjects. As per the convenience, administrator had left the test to the subjects and collect the test when the subjects allowed the administrator and some other had filled up the questionnaire at the spot. After the data collection, gratitude was paid to the subjects and scoring was done.

\section{RESULT:}

The purpose of the study was to find out the emotional intelligence, general well-being, and social support of working and non-working Muslim women. The obtained data was analyzed by using mean, standard deviation, correlation and t-test. The result of the study was analyzed in two steps. In the first step a comparison between working and non-working females were attempted on the scale of emotional intelligence, well-being and social support and in the second step correlation was computed between emotional intelligence, general well-being and social support of working and non-working Muslim females'.

\section{Insert Table 1 here}

Table-1 displays mean, SD and t-value of emotional intelligence, general well-being and social support of working and nonworking Muslim women. Working and non-working Muslim females did not differ on the scale of emotional intelligence and its dimensions, general well-being and social support along with its two dimensions. Two groups differed on only one dimension of social support i.e., informational dimension. Working females scored higher on this dimension as compared to non-working females. Both groups scored more or less similar on all the four scales. Mean difference between the two groups is very low that might be the reason to turn out to be insignificant. Working and non-working females are emotionally intelligent, have better general well-being and both the groups perceived better social support.

\section{Insert Table 2here}

Table 2 records the correlation between emotional intelligence, general well-being and social support of Muslim women. Findings revealed that social support is significantly correlated with emotional intelligence $(\mathrm{r}=.30 \mathrm{p}<.01)$ and general well-being $(\mathrm{r}=.20 \mathrm{p}<.05)$. Correlation between emotional intelligence and general well-being is negative and insignificant.

\section{DISCUSSION}

The purpose of the study was to identify the emotional intelligence, general well-being and social support of working and non-working Muslim women, to examine the relationship between these three variables, and make comparison of working and non-working women on the basis of these variables. Statistics was applied in four steps i.e., (1) correlation between emotional intelligence and general well-being was taken out, (2) correlation between emotional intelligence 


\section{Emotional Intelligence, Social Support and General Well-Being of Working and Non-Working Muslim Women}

and social support was taken out, (3) correlation between social support and general well-being was taken out and (4) significance of difference between means of emotional intelligence, general well-being and social support of working and nonworking Muslim women was taken out. Emotional intelligence is the subset of social intelligence that involves the ability to monitor one's own and other's feelings and emotions, to discriminate among them and to use this information to guide one's thinking and actions (Salovey \& Meyer; 1990). According to the scale Emotional intelligence can be divided into: (a) intra-personal awareness (knowing about one's own emotions), (b) inter-personal awareness (knowing about other's emotions) (c) intrapersonal management (managing one's own emotions) (d) inter-personal management (managing other's emotions).

On the basis of the finding of the study, it is concluded that mean of emotional intelligence of working Muslim women is less than the mean of non-working Muslim women. But this difference is not significant and cannot become population parameter. This clearly indicates that both the groups i.e., working and non-working Muslim women are more or less similar on the basis of emotional intelligence. Women are more emotionally matured and intelligent than men because they might have freedom to express their feeling and emotions as compared to men in our societies. They are more near to their family members and can easily understand the feelings of others.

Studies also revealed that females are more emotionally intelligent than males irrespective of being working and non-working (Thingujam \& Ram 2000; Hall \& Halberstadt, 1994;Brackett \& Mayer, 2003; Mayer, et al., 2002; Schutte, Malouff, Hall, Haggerty, Cooper, Golden, \& Dornheim, 1998; Thingujam \& Ram, 2000). Early studies of the psychological consequences of women's employment indicated that working outside the home generally benefited women emotionally. For example, employed wives exhibited fewer symptoms of psychological distress than full-time homemakers (e.g., Pearlin 1975; Rosenfield 1980). This study also support that females in general are in most cultures trained to be more nurturing, understanding, calm, and society also expects them to have these qualities, so they are in a better position to understand emotion and express it at appropriate times.

Well-being is a general term for the condition of an individual or group, for example their social, economic, psychological, spiritual or medical state; high well-being means that, in some sense, the individual or group's experience is positive while low well-being is associated with negative experience. Mean of general well-being of non-working Muslim women is higher than that of the working Muslim women but it is not significant and cannot become population parameter. This may be due to sample of working women includes only school teachers, which is not very demanding job as compared to other jobs. Teaching profession gives proper arrangements for incentives, leaves for baby caring, holidays, etc. this profession gives sufficient amount of time to be spend with family and due to this less conflict arises and do not affect the well-being of the 


\section{Emotional Intelligence, Social Support and General Well-Being of Working and Non-Working Muslim Women}

teachers. Employment, freedom of expression and change status of women provides opportunity to become self-reliant and hence it might be the one reason for their better well-being. Some studies report mixed results, with some showing positive effects of employment and others showing no effects (e.g., Barnett \& Baruch 1985; Cleary \& Mechanic 1983; Lennon \& Rosenfield 1992; Nelson \& Quick 1985; Rosenfield, 1989).

The social support is the availability of helping relationships and increasing the quality of those relationships (Leavy, 1983). Social support can be bifurcated into three, i.e. emotional support, informational support, and instrumental support. Emotional support consists of warmth, friendliness; it reflects opportunity for expression of concern, encouragement and trust. Informational support helps in defining, understanding and coping with problematic events. Instrumental support could involve giving money, doing another's work giving the custodial care. Score of social support of working and non-working Muslim women is somewhat similar to each other and this difference is not significant. This may be due to teaching profession is one of the most acceptable profession among the Muslim community and less conflict arises on the persuasion of this job by females. Beside this, working women comprise an integral part in generating the economic resources for managing home affairs. In today's world, we are proceeding towards modernization of thoughts which gives opportunity to women to show their potential and capabilities. The rigid mind-set has also been changing regarding the women to pursue job. Many laws are also made that ensure the rights of women which helps in the growth and development of women.

Now the standard deviation (i.e., dispersion of scores around the mean) between the scores obtained by the subjects on each domain of both the group is not much high which clearly indicates that both the group are homogenous in nature. This homogeneity helps in finding the correlation between the variables on the basis of which both the group are evaluated. Correlation between the emotional intelligence and general well-being is negative, and insignificant. It does not necessary that who are physically fit are also high on emotional intelligence. Donaldsonfielder and Bond (2004) compared psychological acceptance and emotional intelligence in terms of their ability to predict various well-being outcomes (i.e., general mental health, physical wellbeing and job satisfaction). Results indicated that acceptance has a greater association with general mental health and physical well-being. Emotional intelligence does not significantly predict any of the well-being outcomes, after accounting for acceptance and job control. Emotional intelligence is not significantly correlated with general well being because there are some other significant variables which define general well-being of an individual.

Correlation between emotional intelligence and social support is significant and positive relationship. This may be due to that people who are emotionally intelligent can understand other more effectively and can have support from them accordingly. It can be supported by some of 


\section{Emotional Intelligence, Social Support and General Well-Being of Working and Non-Working Muslim Women}

the quoted studies e.g., Emma and Dianne (2008) examined the predictive value of social support and emotional intelligence and their interaction effects on subjective well-being. The results showed that social support and emotional intelligence and their interaction effects, significantly predicted subjective well-being. The work plays a central role in people's life. Therefore, the workplace is the ideal setting for the promotion of social and personal competencies which are vital for a healthy and productive life.

Further, the correlation between social support and general well-being is positive and significant. If people have enough support from their near ones then they feel a kind of peace in their mind which in turn gives a good physical well-being. Social support is one of the most important factors in predicting the physical health and well-being of everyone ranging from childhood to older adults. The initial social support given is also a determining factor in successfully overcoming life stress. When people know that they are valued by others is an important factor in helping them to forget negative aspects of their lives, and thinking more positively about their environment. Social support is also major factor in preventing the negative symptoms such as depression and anxiety from developing. Geertje, Karin, and Tineke (2005) examined whether gender differences in health, psychological well-being, and life satisfaction, can be explained by effects of work-related and non-work related sources of social support. Men report better health and psychological well-being than women, whereas women report higher life satisfaction than men.

From the discussion it is concluded that two hypotheses are accepted i.e., the relationship between emotional intelligence and social support would be positive: better the emotional intelligence better the social support, and the relationship between social support and general well-being would be positive: better the social support better the general well-being. Two hypotheses are rejected i.e., the relationship between emotional intelligence and general wellbeing would be positive: better the emotional intelligence better the general well-being but the findings indicates a weak and negative relationship between these variables, and non-working Muslim women would score high on emotional intelligence, social support and general wellbeing in comparison to working Muslim women but finding indicates that there is no significant difference between these two group on the basis of these variables.

Thus this study can be helpful in promoting social support for working Muslim women in different job because after all the modernization we headed toward there are still some problems faced by them e.g. problem in pursuing call centre jobs as it considered negative for women especially in Muslim community. This study can also be helpful in improving the general wellbeing of working as well as non-working Muslim women by providing sufficient leaves, working hours, etc. for working women and providing enough time to non-working women for their hobbies. Support from the organization, family and friends have increasingly been recognized as 


\section{Emotional Intelligence, Social Support and General Well-Being of Working and Non-Working Muslim Women}

useful in reducing stress, protecting health and enhancing quality of life. There is a need to improve the social support network. Social support at the family level is fading away due to increasing nuclear family norms, and at the organizational level due to automation systems.

\section{References}

Abraham. C., Meyrav. Y. H., \&Jacob W., (2009). The relationship between emotional intelligence and psychological wellbeing. Journal of Managerial Psychology, 24, 1, 6678.

Adeyemo, D.A. (2007). Emotional intelligence and the relationship between job satisfaction and organizational commitment of employee in public parastatalsin Oyo State, Nigeria. Pakistan Journal of Social Sciences, 4, 324- 330.

Afroz, N.\&Mittra, R. (2011) Gender Differentiation in Self- actualization and Personality correlates of Professionals. Globalisation and changing status of women: emerging issues and challenges. Ed., Shrivastava, M. \& Sarkar, S. Rawat Publisher, Jaipur

Asha.P \& Suneetha J. Hangal (2001) General wellbeing and emotional intelligence of working and non-working women. Journal of Indian Health Psychology, 6, 2, 201, 1-8.

Asnani, V., Pandey, U. D. \& Sawhney, M. (2004).Social Support and Occupational Health of Working Women. Journal of Health Management, 10, 6, 129-139.

Asthana.M. \&Verma.K.B.(2005). Social support scale. Varanasi. Rupa psychological centre

Ayree, S. (1992). Antecedents and Outcomes of Work-Family Conflict among Married Professional Women: Evidence from Singapore. Human Relations, 45, 813- 837.

Bantam \&House, J.S. (1981).Work Stress and Social Support. Reading, Mass: Addison-Wesley.

Barnes, J.A. (1954). Class and Committees in a Norwegian Island Parish. Human Relations,7, 39-58.

Barnett, R. C. \& Grace K. B. (1985).Women's Involvement in Multiple Roles and Psychological Distress.Journal of Personality and Social Psychology, 49, 135-45.

Beasley, K. (1987). The Emotional Quotient. Mensa Magazine - United Kingdom Edition

Berkman, L.F., Glass, T., Brisette, I. \&Seeman, T.E. (2000). From Social Integration to Health: Durkheim in the New Millennium. Social Science and Medicine, 51, 843-857.

Brackett, M., \& Mayer, J. D. (2003).Convergent, discriminant and incremental validity of competing measures of emotional intelligence. Personality and Social Psychology Bulletin, 29, 1147-1158.

BroughP,\&Pears J (2004). Evaluating the Influence of the Type of Social Support on Job Satisfaction and Work Related Psychological Wellbeing. International Journal of Organizational Behavior, 8, 2, 472-485.

Burrus, J., Betancourt, A., Holtzman, S., Minsky, J., MacCann, C. \& Roberts, R. D.(2012). Emotional Intelligence Relates to Well-Being: Evidence from the Situational Judgment 


\section{Emotional Intelligence, Social Support and General Well-Being of Working and Non-Working Muslim Women}

Test of Emotional Management. Applied Psychology: Health and Well-Being, 4, 151166.

Cleary, Paul \&David Mechanic.(1983). Sex Differences in Psychological Distress among Married People. Journal of Health and Social Behavior 24, 1, 11-21.

Diener, E. (1984). Subjective well-being. Psychological Bulletin, 95, 3, 542-575.

Donaldson- fielder \& F. W. (2004).The relative importance of psychological acceptance and emotional intelligence to workplace well-being. British Journal of Guidance andCounselling, 32, 2, 187-203

Elgar, K., \& Chester, A. (2007). The mental health implication of maternal employment: Australian Journal for the Advancement of Mental Health, 6, 1-9.

Gallagher, E. N., \& Vella-Brodrick, D. A. (2008).Social support and emotional intelligence as predictors of subjective well-being. Personality and Individual Differences, 44, 15511561.

Gardner, H. (1975). The Shattered Mind, New York: Knopf.

Geertje, V., Karin, S. \&Tineke, M. W. (2005).Sources of Social Support as Predictors of Health, Psychological Well-Being and Life Satisfaction among Dutch Male and Female DualEarners. Women \& Health, 41, 2, 43-62.

Glanz, K., Rimer, B.K. \& Lewis, F.M. (2002).Health Behavior and Health Education. Theory, Research and Practice. San Francisco: Wiley \& Sons.

Goleman, D. (1995). Emotional intelligence. New York: Bantam. Hein, S

Hall, J. A., \& Halberstadt, A. G. (1994). Subordination and sensitivity to nonverbal cues: A study of married working women. Sex Roles, 31, 149-165.

Krause, N. \& Kyriakos S. M. (1985).Employment and Well-Being in Mexican American Women. Journal of Health and Social Behavior 26, 15-26.

Kulshrestha. U \& Sen.C. (2006)Subjective Well Being in Relation to Emotional Intelligence and Locus of Control among Executives. Journal of the Indian Academy of Applied Psychology, 32, 2, 93-98.

Kumar, H. \& Varghese, J. (2005).Women's Empowerment: Issues, Challenges and Strategies, Regency Publications, New Delhi.

Leavy. R. L., (1983). Social Support and Psychological Disorder: A Review. Journal of Community Psychology, 11, 3-21.

Lennon, M. C.\& Rosenfield.S. (1992).Women and Mental Health: The Interaction of Job and Family Conditions. Journal of Health and Social Behavior 33, 3 16-27.

Mangal. S. K., \& Mangal. S., (1971).Mangal Emotional Intelligence Inventory. National psychological corporation, Agra.

Mavroveli, S. Petrides. K. V., Rieffe, C., \& Bakker, F. (2007). Trait emotional intelligence, psychological well-being, and peer-rated social competence in adolescence. British Journal of Developmental Psychology, 25, 263-275. 


\section{Emotional Intelligence, Social Support and General Well-Being of Working and Non-Working Muslim Women}

Mayer, J. D., Salovey, P., \& Caruso, D. R. (2000).Models of emotional Intelligence. In R. J Sternberg (Ed.). Handbook of Intelligence (pp. 396-420). Cambridge, England: Cambridge University Press.

Mayer, J. D., Salovey, P., \& Caruso, D. R. (2002). Mayer-Salovey-Caruso Emotional Intelligence test (MSCEIT) Version 2. Toronto, ON: MultiHealth Systems.

Nelson, D. L. \&James C. Q. (1985). Professional Women: Are Distress and Disease Inevitable?Academy of Management Review 10, 206-13.

Nina, O.B. (2005).Emotional intelligence in the workplace: exploring its effects on occupational stress and health outcomes in human service workers.International Journal of Occupational Medicine and Environmental Health, 18, 2, 167- 175.

Payne, W.L. (1985). A study of emotion: developing emotional intelligence; self-integration; relating to fear, pain and desire (theory, structure of reality, problem solving, Contraction/expansion, tuning in/coming out/letting go). A Doctoral Dissertation. Cincinnati, OH: The Union for Experimenting Colleges and Universities

Pearlin, L. I. (1975)."Sex Roles and Depression." Pp. 191-207 in Life-span Developmental Psychology: Normative Life Crises, edited by N. Datan and L. H. Ginsberg. New York: Academic Press.

Rani.A. \&Darolia C. R. (2011).Work-Family Interference and Well-being in Indian Women: Mediating Role of Emotional Intelligence.Journal of the Indian Academy of Applied Psychology.37, 2, 25-33.

Reuven Bar-On (2012). The Impact of Emotional Intelligence on Health and Wellbeing, Emotional Intelligence -New Perspectives and Applications

Rosenfield, S. (1980).Sex Differences in Depression: Do Women Always Have Higher Rates? Journal of Health and Social Behavior 21, 33-42.

Rosenfield, S. (1989).The Effects of Women's Employment: Personal Control and Sex Differences in Mental Health. Journal of Health and Social Behavior, 30, 77-91.

Salovey, P., \& Mayer, J. (1990).Emotional intelligence.Imagination, Cognition, and personality, 9, 3, 185-211.

Salovey, P., \& Mayer, J.D. (1990). Emotional intelligence. Imagination, Cognition, and Personality, 9, 185-211.

Schutte, N., Malouff, J., Hall, E., Haggerty, D., Cooper, J., Golden, D., \&Dornheim, L. (1998).Development and validation of a measure of emotional intelligence. Personality and Individual Differences, 25, 167-177.

Thingujam, N. S. (2004). Current trend and future perspective on emotional intelligence. Psychological Studies, 49, 155-166.

Thingujam, N. S., \& Ram, U. (2000). Emotional Intelligence Scale: Indian norms. Journal of Education and Psychology, 58, 40-48.

Thingujam, N.S. (2002). Emotional intelligence: What is the evidence? Psychological Studies, 47, 54-69. 


\section{Emotional Intelligence, Social Support and General Well-Being of Working and Non-Working Muslim Women}

Thorndike, R. L., \& Stein, S. (1937). An evaluation of the attempts to Measure social intelligence. Psychological Bulletin, 34, 275-284.

Trinidad, D. R., \& Johnson, C. A. (2001). The association between emotional intelligence and early adolescent tobacco and alcohol use. Personality and Individual Differences, 32, 95-105.

Tsaousis, I. \& Nikolaou, I. (2005).Exploring the Relationship between Emotional Intelligence and Physical and Psychological Health. Stress and Health,21, 77- 86.

Van Rooy, D.L. \&Viswesvaran, C. (2004). Emotion intelligence: A meta-analytic investigation of predictive validity and nomological net. Journal of Vocational Behavior, 65, 71-95.

Verma.S.K. \&Verma.A. (2005). PGI Generalwell-being measure. NationalPsychological Corporation, Agra.

Wechsler, D. (1940). No intellective factors in general intelligence. Psychological Bulletin,37, 444-445.

Table 1: Mean, SD and $t$-value of working $(N=40)$ and non-working $(N=40)$ Muslim females on the scale of Emotional Intelligence, General Well-Being and Social Support.

\begin{tabular}{|l|c|c|c|c|l|}
\hline \multirow{2}{*}{ Emotional intelligence } & \multicolumn{2}{|c|}{$\begin{array}{c}\text { Working Female } \\
\text { (N=40) }\end{array}$} & \multicolumn{2}{c|}{$\begin{array}{c}\text { Non-Working } \\
\text { Female (N=40) }\end{array}$} & \\
\cline { 2 - 6 } & Mean & SD & Mean & SD & t-value \\
\hline Intra-personal awareness & 50.02 & 9.81 & 49.10 & 9.27 & $0.47^{\mathrm{NS}}$ \\
\hline Inter-personal awareness & 49.81 & 9.96 & 50.02 & 9.85 & $0.01^{\mathrm{NS}}$ \\
\hline Intra-personal management & 50.12 & 9.78 & 50.01 & 9.85 & $0.04^{\mathrm{NS}}$ \\
\hline Inter-personal management & 50.01 & 9.84 & 50.01 & 9.85 & $0.00^{\mathrm{NS}}$ \\
\hline Emotional Intelligence Total & 50.00 & 9.83 & 50.00 & 9.83 & $0.00^{\mathrm{NS}}$ \\
\hline General well being & 49.02 & 11.02 & 49.97 & 9.71 & $0.00^{\mathrm{NS}}$ \\
\hline \multicolumn{1}{|c|}{ Emotional support } & 49.69 & 9.70 & 49.91 & 8.70 & $0.47^{\mathrm{NS}}$ \\
\hline Informational support & 48.45 & 8.21 & 43.41 & 9.37 & $2.24^{*}$ \\
\hline \multicolumn{1}{|c|}{ Instrumental support } & 50.12 & 12.14 & 50.71 & 10.77 & $0.48^{\mathrm{NS}}$ \\
\hline \multicolumn{1}{|c}{ Total } & 49.48 & 9.33 & 48.63 & 10.39 & $0.68^{\mathrm{NS}}$ \\
& & & & & \\
\hline
\end{tabular}

Significant at *p<0.05 


\section{Emotional Intelligence, Social Support and General Well-Being of Working and Non-Working Muslim Women}

Table 2:Correlation Coefficient between Emotional Intelligence, General Well-Being, and Social Support of Working and Non-working Muslim Women $(N=80)$.

\begin{tabular}{|c|c|c|}
\hline & $\begin{array}{c}\text { General Well- } \\
\text { Being }\end{array}$ & $\begin{array}{c}\text { Social } \\
\text { Support }\end{array}$ \\
\hline $\begin{array}{c}\text { Emotional } \\
\text { intelligence }\end{array}$ & -0.08 & $0.30^{* *}$ \\
\hline $\begin{array}{c}\text { General well } \\
\text { being }\end{array}$ & - & $0.20^{*}$ \\
\hline
\end{tabular}

Significant at ${ }^{*} \mathrm{p}<0.05,{ }^{* *} \mathrm{p}<0.01$

How to cite this article: N Afroz (2016), Emotional Intelligence, Social Support and General Well-Being of Working and Non-Working Muslim Women, International Journal of Indian Psychology, Volume 3, Issue 3, No. 11, DIP: 18.01.191/20160303, ISBN: 978-1-365-21307-6 